\title{
BIRD RINGING IN ANTIKYTHIRA ISLAND (S GREECE)
}

\author{
Maria Dimaki, Clairie Papazoglou and Triantaphyllos Akriotis
}

\begin{abstract}
Dimaki M., Papazoglou C., Akriotis T. 2006. Bird ringing in Antikythira island (S Greece). Ring 28, 1: 85-94.

For the period of 1998-2004 we carried out bird ringing on Antikythira island (Greece). During this period, with the help of 39 volunteers, we caught a total of 9455 birds belonging to 73 different species. On our best day we ringed 441 birds in the spring of 2002.

In the spring of 2004 we obtained the maximum number of bird species, which was 52 species, and the maximum number of birds, which was 2886 in the period of 25 days. During this study we had four controls and two recoveries. Most of them were found or ringed during the spring of 2004.
\end{abstract}

M. Dimaki (corresponding author), the Goulandris Natural History Museum, 100, Othonos St., Kifissia, GR-145 62, Greece; Hellenic Ornithological Society, 24 Vas. Irakliou St. Athens, GR-106 82, Greece, E-mail: mdim@gnhm.gr; C. Papazoglou, Hellenic Ornithological Society, 24 Vas. Irakliou St. Athens, GR-106 82, Greece; T. Akriotis, Hellenic Bird Ringing Centre, P.O. Box 4265, GR-10210 Athens, Greece; Department of Environment, University of the Aegean, "Xenia” building, GR-81100 Mytilene, Lesvos island, Greece

Key words: ringing, south Greece

In this paper we present ringing data for the period of 1998-2004 (altogether 118 days) on Antikythira island ( $\mathrm{S}$ Greece). This is the first report on the Ringing Scheme of Antikythira. We also present the controls and recoveries we had during these field trips.

The island is a very important stopover site for bird migration. Most autumn migrants move across Greece from early or mid-August to late October or early November, whereas return movements start mainly from mid-March and last up to mid-May (Handrinos and Akriotis 1997).

Additional information about bird migration in western Greece can be found in a paper based on ringing on the Strophades Islands (Schogolev and Dimaki 1996) and we try to compare this information with ours. Data on bird migration in Greece can also be found in the book of Handrinos and Akriotis (1997).

Antikythira $\left(35^{\circ} 51^{\prime} \mathrm{N}, 23^{\circ} 18^{\prime} \mathrm{E}\right)$ is a small island located south of the Peloponnese, between the islands of Kythira and Crete. The distance from Kasteli (Kissa- 
mos), Crete, is 26 miles and the maximum altitude of the island is $378 \mathrm{~m}$. The area is about $20 \mathrm{~km}^{2}$ and the coastline is $24 \mathrm{~km}$ long. Antikythira and the following islets belong to the county of Kythira: Thymontes, Pseira, Plakoulithra, Lagouvardos and Prasonissi (or Pori).

The dominant vegetation on Antikythira is low maquis and phrygana, while part of the island is cultivated by cereals (see Plate I and II). Antikythira is one of the drier locations in Greece, receiving annually less than $200 \mathrm{~mm}$ of rainfall (Dafis $e t$ al. 1996).

Antikythira is a "Natura 2000" site and under EU legislation. It is a "Special Protection Area". It is also an "Important Bird Area" of Greece (Bourdakis and Vareltzidou 2000).

In 1997 the Municipality of Antikythira donated the old secondary school building to the Hellenic Ornithological Society in order to be used as the Scientific Ornithological Station. The basic aims of the Ornithological Station of Antikythira are the following (Papaconstantinou 2004): (1) study of the bird migration by ringing; (2) study of the migration of raptors; (3) monitoring and protection of some important bird species, with emphasis on the Eleonora's Falcon (Falco eleonorae); (4) training in bird ringing.

Since 1998 the Hellenic Ornithological Society and the Hellenic Bird Ringing Centre have been organizing bird ringing on Antikythira island. The birds were caught using mist-nets during nine netting and ringing sessions between April 1998 and September/October 2004.

The nets were set in the following habitats: a) olive groves, b) maquis vegetation, c) tall trees (figs and almond trees) with some reeds and d) cultivated land.

Netting sessions took place in a total of 118 days. Most nettings were carried out from 5.30 a.m. (range: 5.15-6.00 a.m., depending on weather conditions) in spring or $6.30 \mathrm{a} . \mathrm{m}$. in the autumn, until 4.00-9.00 p.m., depending on the weather conditions and the number of birds that were caught on the day. On days with very low bird counts we often closed the nets during the afternoon. Our mist-nets were $2.5 \mathrm{~m}$ high and 10-14 m long. We used 8 to 25 nets, depending on the weather conditions (such as wind).

All trapped birds were identified, ringed, aged, sexed, and measured according to Svensson (1992). The measurements collected were: wing length - maximum chord, tarsus length, weight, fat - according to Kaiser (1993), and muscle score - according to Bairlein (1995). The species identification, age and sex determination of non-passerines was based on Baker (1993). The general methodology was according to the Ringers' Manual (Akriotis 2000).

A total of 9455 birds belonging to 73 species were caught and ringed during the 9 ringing sessions. Table 1 gives the dates of ringing sessions as well as the total number of birds ringed during each season, the number of species and the maximum birds per day in each ringing session. Figure 1 illustrates distribution of the ringing activity over the years and seasons. Table 2 summarizes the number of birds from particular species ringed on Antikythira island. 
Table 1

Dates of ringing sessions, totals of birds ringed, number of species, and the maximum of a day at each ringing session

\begin{tabular}{|c|c|c|c|c|c|}
\hline Time & $\begin{array}{c}\text { Number } \\
\text { of days }\end{array}$ & $\begin{array}{c}\text { Number } \\
\text { of species }\end{array}$ & Total number & $\begin{array}{c}\text { Maximum } \\
\text { catch in a day }\end{array}$ & $\begin{array}{c}\text { Date of maxi- } \\
\text { mum catch }\end{array}$ \\
\hline 16-29 Apr. 1998 & 14 & 49 & 1446 & 343 & 25 Apr. 1998 \\
\hline 13-21 Sep. 1998 & 9 & 29 & 226 & 77 & 18 Sep. 1998 \\
\hline 21-26 Apr. 1999 & 6 & 30 & 266 & 60 & 20 Apr. 1999 \\
\hline 1-13 Sep. 1999 & 13 & 29 & 487 & 102 & 9 Sep. 1999 \\
\hline 1-11 May 2002 & 11 & 47 & 2246 & 441 & 5 May 2002 \\
\hline 7-18 May 2003 & 12 & 33 & 873 & 222 & 16 May 2003 \\
\hline 10-19 Sep. 2003 & 10 & 27 & 308 & 65 & 13 Sep. 2003 \\
\hline 8 Apr.-1 May 2004 & 25 & 52 & 2886 & 406 & 20 Apr. 2004 \\
\hline 16 Sep.-3 Oct. 2004 & 18 & 35 & 717 & 88 & 29 Sep. 2004 \\
\hline
\end{tabular}

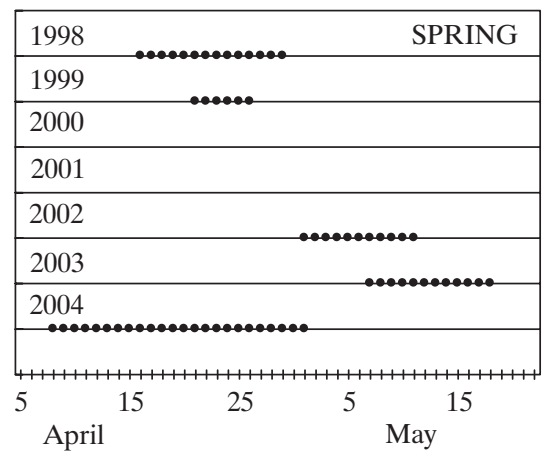

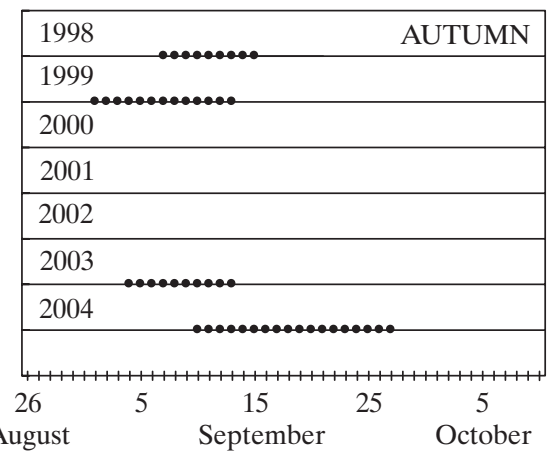

Fig. 1. Distribution of ringing activity (dots) over the years and seasons

During the work we had six ringing recoveries that are presented below:

Oriolus oriolus

GRA $4001021 \mathrm{~F}$ ad.

26 April 2002

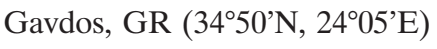

12 May 2003

Antikythira, GR $\left(35^{\circ} 51^{\prime} \mathrm{N}, 23^{\circ} 18^{\prime} \mathrm{E}\right)$

Hirundo rustica

FIH 610895J M ad.

4 Sep. 2002

Turku, FI (60² $\left.24^{\prime} \mathrm{N}, 22^{\circ} 15^{\prime} \mathrm{E}\right)$

28 Apr. 2003

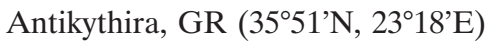

Sylvia borin

ITB L821731

(no data) Italy

ad. $\quad 30$ Apr. 2004

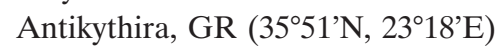

Riparia riparia

GRA A130311 ad.

15 Apr. 2004

Antikythira, GR $\left(35^{\circ} 51^{\prime} \mathrm{N}, 23^{\circ} 18^{\prime} \mathrm{E}\right)$

25 Jun. 2004

Tiszatelek, HU ( $\left.48^{\circ} 11^{\prime} \mathrm{N}, 21^{\circ} 49^{\prime} \mathrm{E}\right)$

Streptopelia turtur 
GRA N201026 M ad.

25 Apr. 2004

7 Aug. 2004

GRA N200974 F ad.

11 Apr. 2004

4 Sep. 2004

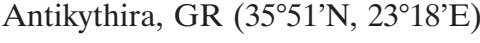

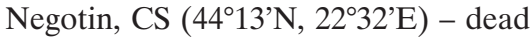

Antikythira, GR $\left(35^{\circ} 51^{\prime} \mathrm{N}, 23^{\circ} 18^{\prime} \mathrm{E}\right)$

Crete, GR $\left(35^{\circ} 11^{\prime} \mathrm{N}, 25^{\circ} 17^{\prime} \mathrm{E}\right)-$ dead

Table 2

Species list of birds ringed in Antikthira in 1998-2004

Individuals of a few species caught were not ringed (Total $=0$ ).

\begin{tabular}{|c|c|c|c|c|c|c|c|c|c|c|}
\hline & 195 & & 19 & & 2002 & 20 & & 200 & & \\
\hline & Spring & $\begin{array}{l}\text { Au- } \\
\text { tumn }\end{array}$ & Spring & $\begin{array}{l}\text { Au- } \\
\text { tumn }\end{array}$ & Spring & Spring & $\begin{array}{c}\mathrm{Au}- \\
\text { tumn }\end{array}$ & Spring & $\begin{array}{l}\text { Au- } \\
\text { tumn }\end{array}$ & Total \\
\hline Ixobrychus minutus & & & & & & & & & & $\mathbf{0}$ \\
\hline Circus aeruginosus & 1 & & & & & & & & & 1 \\
\hline Circus macrourus & & & & & 1 & & & & & 1 \\
\hline Accipiter brevipes & & & & & & & & & & $\mathbf{0}$ \\
\hline Accipiter nisus & & 1 & & & & & & 1 & & 2 \\
\hline Falco vespertinus & & & & & & & & & & $\mathbf{0}$ \\
\hline Falco tinnunculus & 4 & & 3 & & & 1 & & 1 & & 9 \\
\hline Coturnix coturnix & & & & & & & & 1 & & 1 \\
\hline Gallinago media & 1 & & & & & & & & & 1 \\
\hline Tringa glareola & 1 & & & & & & & 1 & & 2 \\
\hline Actitis hypoleucos & 1 & & & & & & & & & 1 \\
\hline Philomachus pugnax & & & & & & & & 1 & & 1 \\
\hline Streptopelia decaocto & & & & & & & & & & $\mathbf{0}$ \\
\hline Streptopelia turtur & 37 & 1 & 9 & 14 & 27 & 19 & 10 & 91 & 5 & 213 \\
\hline Cuculus canorus & 4 & & & 1 & 2 & 1 & 3 & 11 & & 22 \\
\hline Tyto alba & & & & & & & & & & $\mathbf{0}$ \\
\hline Otus scops & 1 & 1 & 5 & 1 & 1 & 1 & & 9 & 9 & 28 \\
\hline Caprimulgus europaeus & 2 & 1 & & & 1 & 5 & & 49 & & 58 \\
\hline Merops apiaster & & & 1 & & 20 & 4 & & 16 & & 41 \\
\hline Merops persicus & & & & & & & & 1 & & 1 \\
\hline Uрира ерорs & 7 & 1 & 1 & 1 & & & 2 & 10 & 1 & 23 \\
\hline Jynx torquilla & 9 & 1 & & 2 & 2 & & 2 & 14 & 5 & 35 \\
\hline Delichon urbica & 38 & & 13 & & & 1 & & 29 & & 81 \\
\hline Riparia riparia & 127 & & 5 & & 4 & 13 & & 26 & 1 & 176 \\
\hline Hirundo rustica & 66 & 11 & 12 & & 1 & 1 & & 101 & 44 & 236 \\
\hline Hirundo daurica & & & & & 1 & & & & & 1 \\
\hline Anthus trivialis & 53 & 3 & 22 & 1 & 22 & 1 & 4 & 172 & 6 & 284 \\
\hline Anthus cervinus & & & & & & & & 1 & & 1 \\
\hline Anthus campestris & & & & & 1 & & & & & 1 \\
\hline Motacilla alba & & & & & & & & & & $\mathbf{0}$ \\
\hline Motacilla flava & 79 & 1 & 1 & 8 & 28 & 6 & 1 & 7 & 1 & 132 \\
\hline Erithacus rubecula & & & & & 1 & & & 4 & 61 & 66 \\
\hline Luscinia luscinia & & & 1 & & & & & & 1 & 2 \\
\hline Luscinia megarhynchos & 38 & 5 & 10 & 18 & 12 & 4 & 3 & 76 & 17 & 183 \\
\hline Luscinia svecica & 1 & & & & & & & & & 1 \\
\hline Phoenicurus phoenicurus & 14 & 3 & 8 & 12 & 42 & 7 & 15 & 49 & 46 & 196 \\
\hline Saxicola rubetra & 23 & & & 16 & 31 & 6 & 7 & 67 & 8 & 158 \\
\hline Oenanthe oenanthe & & & & 4 & 1 & & 2 & 4 & 2 & 13 \\
\hline
\end{tabular}




\begin{tabular}{|c|c|c|c|c|c|c|c|c|c|c|}
\hline & \multicolumn{2}{|c|}{1998} & \multicolumn{2}{|c|}{1999} & \multirow{2}{*}{\begin{tabular}{|l}
2002 \\
Spring
\end{tabular}} & \multicolumn{2}{|c|}{2003} & \multicolumn{2}{|c|}{2004} & \multirow[b]{2}{*}{ Total } \\
\hline & Spring & $\begin{array}{c}\text { Au- } \\
\text { tumn }\end{array}$ & Spring & $\begin{array}{l}\text { Au- } \\
\text { tumn }\end{array}$ & & Spring & $\begin{array}{c}\mathrm{Au}- \\
\text { tumn }\end{array}$ & Spring & $\begin{array}{l}\text { Au- } \\
\text { tumn }\end{array}$ & \\
\hline Oenanthe hispanica & 2 & 1 & & & & & 1 & 2 & 1 & 7 \\
\hline Oenanthe isabellina & & & & & & & & & & $\mathbf{0}$ \\
\hline Turdus philomelos & & & & & & & & & & $\mathbf{0}$ \\
\hline Cettia cetti & & 1 & & & & & & & & 1 \\
\hline Acrocephalus schoenobaenus & 34 & & 12 & 2 & 397 & 72 & 1 & 69 & 5 & 592 \\
\hline Locustela luscinioides & & & & & & & & 1 & & 1 \\
\hline Acrocephalus scirpaceus & 5 & 2 & 3 & 5 & 9 & 11 & 5 & 5 & 1 & 46 \\
\hline Acrocephalus palustris & & & & & 1 & & & & 2 & 3 \\
\hline Acrocephalus arundinaceus & 18 & 2 & 5 & 1 & 36 & 12 & 2 & 31 & 2 & 109 \\
\hline Hippolais pallida & 3 & & & 1 & 22 & 20 & & 1 & & 47 \\
\hline Hippolais icterina & 28 & 35 & & 60 & 174 & 59 & 6 & 11 & 15 & 388 \\
\hline Sylvia cantillans & 9 & 5 & 1 & 12 & 7 & & 7 & 6 & & 47 \\
\hline Sylvia melanocephala & 1 & & & & 1 & & & 1 & 1 & 4 \\
\hline Sylvia nisoria & & & & 1 & & & & & & 1 \\
\hline Sylvia hortensis & 2 & & & & & & & & & 2 \\
\hline Sylvia curruca & & 1 & & & 1 & & & 1 & 5 & 8 \\
\hline Sylvia communis & 30 & 14 & 19 & 19 & 139 & 25 & 21 & 53 & 19 & 339 \\
\hline Sylvia borin & 133 & 45 & 10 & 115 & 801 & 403 & 105 & 270 & 153 & 2035 \\
\hline Sylvia atricapilla & 20 & 7 & 1 & 6 & 14 & 5 & 9 & 34 & 105 & 201 \\
\hline Phylloscopus orientalis & 8 & & 1 & & 1 & & & 3 & & 13 \\
\hline Phylloscopus sibilatrix & 172 & 9 & 24 & 20 & 63 & 14 & 7 & 389 & 19 & 717 \\
\hline Phylloscopus collybita & 2 & & 1 & & 2 & 1 & & 3 & & 9 \\
\hline Phylloscopus trochilus & 34 & 19 & 19 & 49 & 36 & 17 & 32 & 135 & 55 & 396 \\
\hline Phylloscopus nitidus & & 1 & & & & & & & & 1 \\
\hline Muscicapa striata & 74 & 12 & 8 & 44 & 115 & 62 & 31 & 153 & 65 & 564 \\
\hline Ficedula hypoleuca & 203 & & 30 & 6 & 117 & 10 & & 527 & 3 & 896 \\
\hline Ficedula albicollis & 56 & 3 & 13 & 19 & 32 & 6 & 6 & 107 & 4 & 246 \\
\hline Ficedula semitorquata & & & & & 6 & & & 6 & & 12 \\
\hline Ficedula parva & 1 & 24 & & 6 & & & 14 & & 36 & 81 \\
\hline Parus caeruleus & & & & & 1 & & & & & 1 \\
\hline Lanius collurio & 1 & 12 & & 26 & & 2 & 8 & & 6 & 55 \\
\hline Lanius senator & 35 & & 5 & & 27 & 6 & 3 & 87 & & 163 \\
\hline Oriolus oriolus & 52 & 4 & 22 & 17 & 32 & 31 & 1 & 232 & 11 & 402 \\
\hline Passer hispaniolensis & 9 & & & & 6 & 40 & & 11 & 1 & 67 \\
\hline Passer italiae & 4 & & & & & & & 1 & & 5 \\
\hline Passer sp. & & & & & 2 & & & & & 2 \\
\hline Serinus serinus & & & & & & & & & & $\mathbf{0}$ \\
\hline Fringilla coelebs & & & & & 1 & 2 & & 2 & & 5 \\
\hline Carduelis chloris & 1 & & & & 2 & & & 2 & & 5 \\
\hline Carpodacus erythrinus & & & & & & & & & 1 & $\mathbf{1}$ \\
\hline Emberiza hortulana & 1 & & 1 & & 1 & & & 1 & & 4 \\
\hline Emberiza caesia & 1 & & & & & & & & & 1 \\
\hline Miliaria calandra & & & & & & 1 & & & & 1 \\
\hline Emberiza melanocephala & & & & & 2 & 4 & & & & 6 \\
\hline Total & 1446 & 226 & 266 & 487 & 2246 & 873 & 308 & 2886 & 717 & 9455 \\
\hline
\end{tabular}


The presence of some species is noteworthy, like the Green Warbler (Phylloscopus nitidus) the Blue Cheeked Bee-eater (Merops persicus) and the Common Rosefinch (Carpodacus erythrinus).

The Green Warbler in the autumn of 1998 was the first record of this species in Greece. The distribution of this species includes northern Turkey, Caucasus, as far as northern Iran and Afghanistan. Its migration movements include mostly south-east to winter in southern India and Sri Lanka. The species has also been observed in the United Kingdom, in Germany, Ukraine, Israel, and Kuwait (Papazoglou 1999).

The Blue Cheeked Bee-eater was ringed in the spring of 2004. This species has been reported from Greece as a rare and irregular passage migrant. Most of the Greek records come from Crete and Dodecanese from April (Handrinos and Akriotis, 1997).

The Common Rosefinch has been reported from the Greek islands of Chios, Lesvos, and Crete and is considered as an accidental visitor in Greece (Handrinos and Akriotis 1997). It was ringed in the autumn of 2004.

As in other places of the Mediterranean like Cyprus (Flint and Stewart 1992) and Sicily (Iapichino and Massa 1989) the spring passage in Greece is generally more evident than autumn passage, with a wider variety of species and larger numbers of individuals. Our results are in accordance with this, a greater number of birds and even more species were caught during spring than in autumn (Table 1 and 2). According to Handrinos and Akriotis (1997) this may be due to a combination of the following reasons: (1) in spring migrants arrive in Greece after having made a long sea and sometimes desert crossing and are more in need of rest and refueling than in autumn; (2) the more variable weather in spring; and (3) the greater amount of food and suitable habitats in spring. We should also consider that the number of birds that were caught depends on the number of days of ringing sessions (Table 1).

The bird species we caught in Antikythira and those from Strophades (Schogolev and Dimaki 1996) are comparable. The commonest Luscinia species is the Nightingale (L. megarhynchos) in both places. This was expected, as the Thrush Nightingale (L. luscinia) is more common in the autumn migration than in the spring migration and in eastern parts of Greece. As far as the Bluethroat (L. svecica) is concerned, it is a rare and irregular winter visitor and passage migrant in Greece (Handrinos and Akriotis 1997), and only one was ringed in Antikythira.

In Strophades the only Lanius species that was observed, in spring, was the Woodchat Shrike (L. senator), in Antikythira we ringed both Woodchat Shrikes and Red-backed Shrikes (L. collurio) - the Woodchat Shrikes mainly in the spring ringing sessions and the Red-backed Shrikes during the autumn sessions. This was expected according to Handrinos and Akriotis (1997), the Red-backed Shrike being a very common autumn migrant while the spring passage of this species is much smaller. The opposite stands for the Woodchat Shrike.

The most common species of the genus Sylvia in Antikythira was the Garden Warbler (S. borin), followed by the Whitethroat (S. communis). In Strophades the 
most common species of the genus Sylvia was the Whitethroat followed by the Subalpine Warbler ( $S$. cantillans).

Among species of the genus Phylloscopus the most abundant was the Wood Warbler (P. sibilatrix), followed by the Willow Warbler (P. trochilus), a fact that is in accordance with the findings from Strophades. We ringed Chiffchaffs $(P$. collybita) only in spring. This was expected, because Chiffchaffs are more widespread and numerous in Greece from mid-October to more or less early April (Handrinos and Akriotis 1997).

As far as Muscicapidae family is concerned, the Pied Flycatcer (Ficedula hypoleuca) was the second more common bird that we ringed. The Spotted Flycatcher (Muscicapa striata) was also a quite common species on Antikythira (Table 2). Very important was the presence of the Red-breasted Flycatcher ( $F$. parva) during autumn migration. The species is considered as a rare and local summer visitor, and a scarce passage migrant in Greece (Handrinos and Akriotis 1997).

The great numbers of Turtle Doves (Streptopelia turtur) and Golden Orioles (Oriolus oriolus) ringed on the island are noteworthy. As it was expected, we had more birds of both species during spring, as these species are much more common in the spring passage, particularly in western Greece for Turtle Doves (Handrinos and Akriotis 1997). So far there have been 38 ringing recoveries of Turtle Doves in Greece concerning birds ringed mainly in the Czech Republic and Hungary and some from Italy, Poland, Slovakia, Austria, Slovenia, Ukraine, Cyprus and the Republic of Chad (Handrinos and Akriotis 1997). There have been 31 ringing recoveries of Golden Orioles in Greece concerning birds ringed mainly in Hungary, Poland, the Czech Republic, Italy, S. France and Corsica, Germany, Yugoslavia, Latvia, Slovakia, and Romania (Handrinos and Akriotis 1997).

Greece favours the migratory movements of birds along the north-south axis, because of the geographical location, the shape and relief of the country (Handrinos and Akriotis 1997). The most important migration routes in Greece are: (1) the eastern route that covers the west coastline of Asia Minor and the Greek islands of eastern Aegean; (2) the route that goes through central Greece; (3) the route that covers the western coastline of Greece (Casement 1966, Kominos 2004). The two latest routes converge at Antikythira. The island is an ideal place for bird ringing and it is therefore very important to continue this project.

\section{ACKNOWLEDGEMENTS}

We would like to thank the Leventis Foundation and Stephen Rumsey of the Wetland Trust who made these trips possible. We are grateful for the assistance of the 39 volunteers with ringing. Thanks to the mayor Andreas Charchalakis for his assistance and the landowners of Antikythira who allowed ringing to take place on their land. 


\section{REFERENCES}

Akriotis T. 2000. [Ringers Manual]. Hellenic Bird Ringing Centre: 50 pp. (In Greek).

Bairlein F. 1995. European-African Songbird Migration Network. Manual of Field Methods. Vogelwarte Helgoland, Wilhelmshaven.

Baker K. 1993. Identification guide to European non-Passerines. BTO Guide 24.

Bourdakis S., Vareltzidou S. 2000. Southern Europe. In: Heath M.F., Evans M.I. (Eds). Important Bird Areas in Europe: Priority sites for conservation. Cambridge, UK, BirdLife International, Greece, BirdLife Conserv. Ser. 8: 261-333.

Casement M.B. 1966. Migration across the Mediterranean observed by radar. Ibis 108: 461-491.

Dafis S., Papastergiadou E., Georghiou K., Babalonas D., Georgiadis T., Papageorgiou M., Lazaridou T., Tsiaoussi V. (Eds). 1996: Directive 92/43/EEC The Greek "Habitat" Project Natura 2000: An Overview. Life Contract B4-3200/94/756, commission of the European Communities DG XI, The Goulandris Natural History Museum-Greek Biotope / Wetland Centre / University of Athens / University of Thessaloniki / University of Patra. p. 917.

Flint P.R., Stewart P.F. 1992. The Birds of Cyprus. B.O.U. Check-list No 6, B.O.U., Tring.

Handrinos G., Akriotis T. 1997. The Birds of Greece. Christopher Helm (Ed.). London.

Iapichino C., Massa B. 1989. The Birds of Sicily. B.O.U. Check-list No 11, B.O.U., Tring.

Kaiser A. 1993. A new multi-category clasification of subcutaneous fat deposits of songbirds. J. Field Ornithol. 64, 2: 246-255.

Kominos T. 2004. [Kythira - Antikythira. A new vision in raptor's migration in Mediterranean.] Ionos (Newsletter of the Hellenic Ornithological Society) 19: 8-9. (In Greek).

Papaconstantinou Ę. 2004. [Ornithological Station of Antikythira (OSA).] Ionos (Newsletter of the Hellenic Ornithological Society) 19: 10-11. (In Greek).

Papazoglou C. 1999. [First observation of the Green Warbler Phylloscopus trochiloides nitidus in Greece.] Ionos (Newsletter of the Hellenic Ornithological Society) 8: 21. (In Greek).

Schogolev I., Dimaki M. 1997. Bird migration in the spring at Strophades islands (Ionian Sea, Greece). Ring 18, 1-2: 89-96.

Svensson L. 1992. Identification guide to European Passerines. Stockholm, Sweden. 


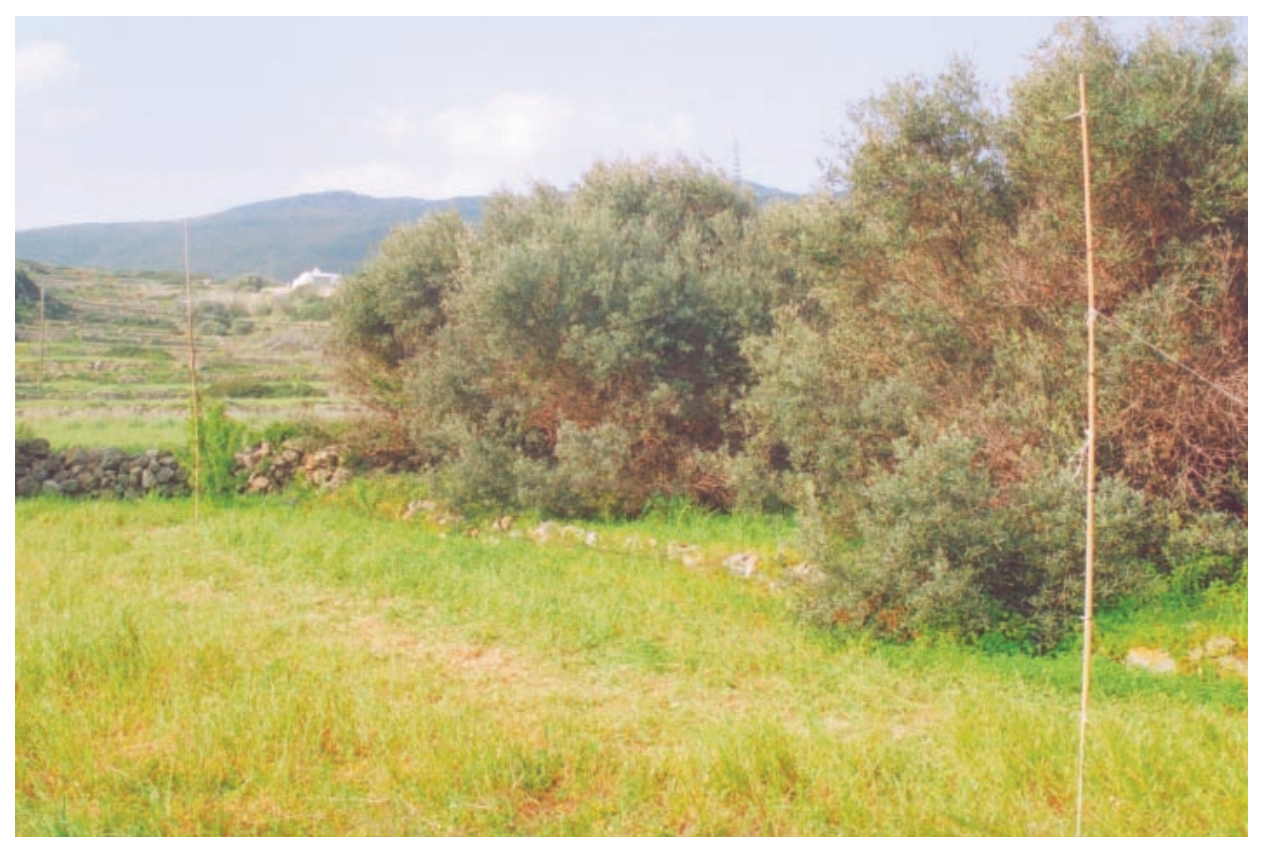

Plate I-1. A net site near an olive grove and a meadow

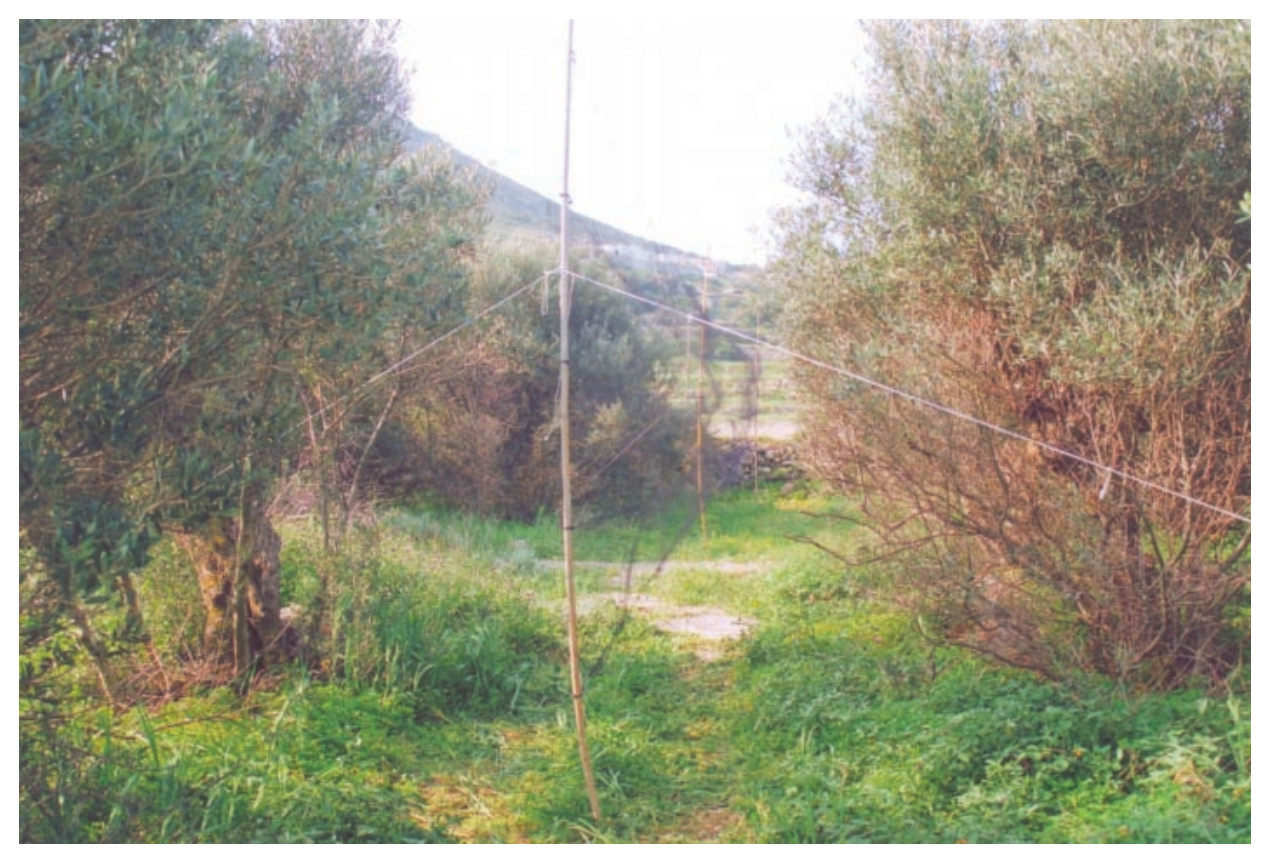

Plate I-2. A net site in an olive grove 


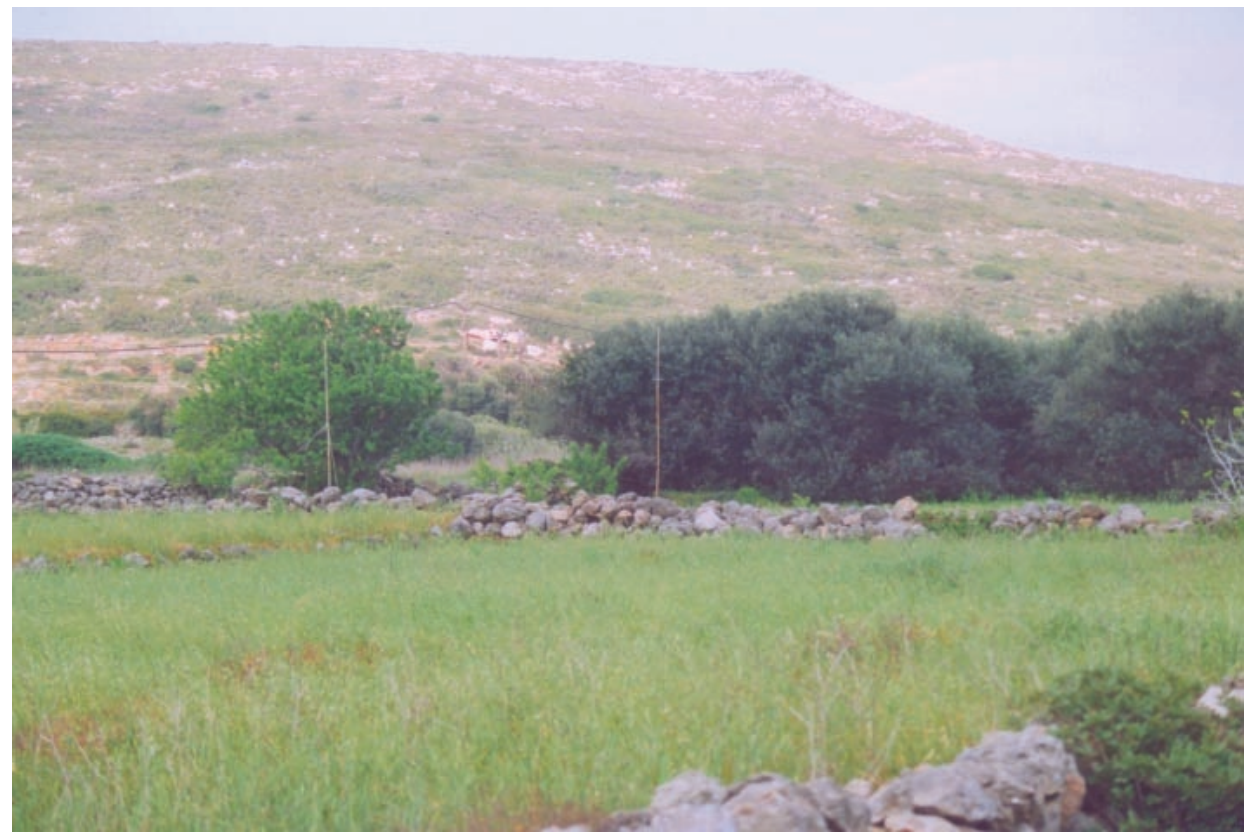

Plate II-1. A net site near cultivated land

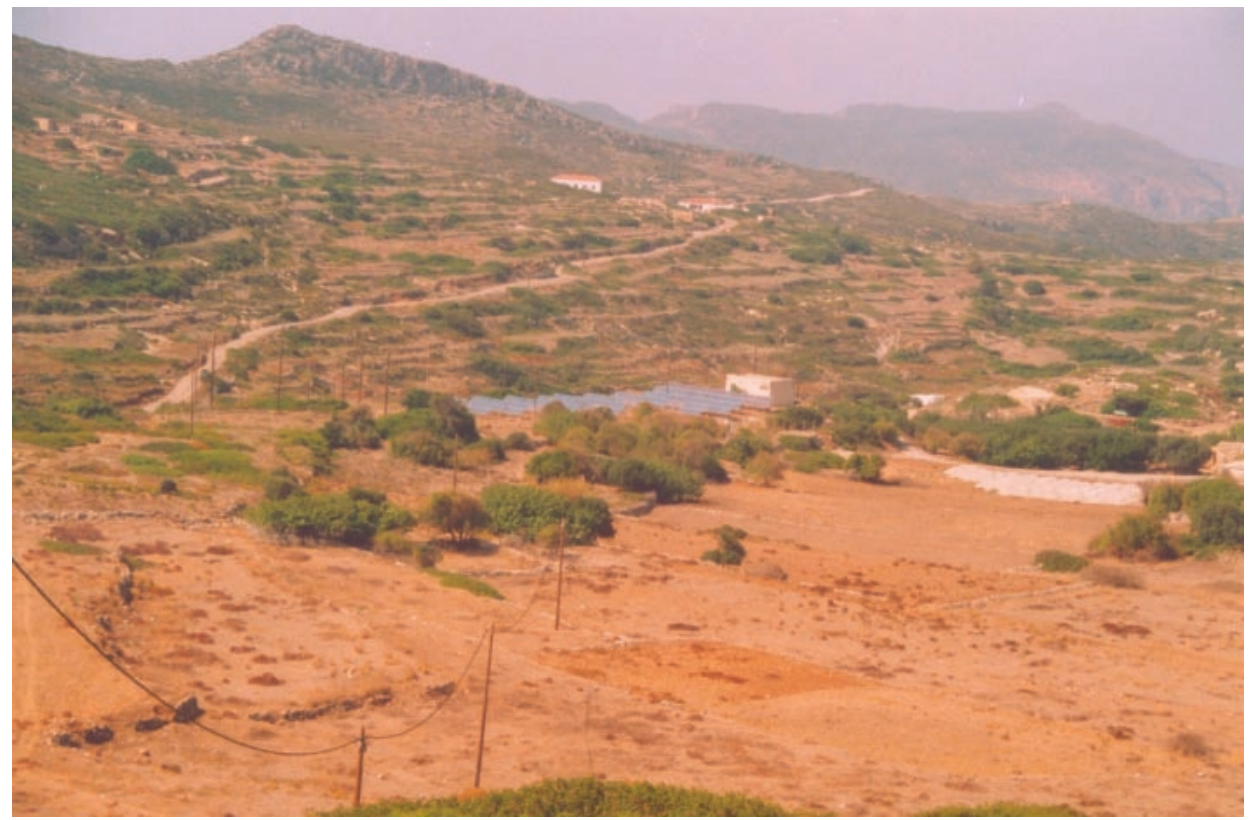

Plate II-2. A view of the island. The ringing place is the area with vegetation. The building at the top of the photo is the Ornithological Station

Photos by M. Dimaki 